to the rank-and-file, Adamic brilliantly reveals, with great verve and insight, why an American worker would much prefer to be a racketeer and criminal than an honest industrial labourer. Poverty in America, Adamic argues, drives the worker into the underworld, not into the radical movement. There is hope that the American working class will some day embrace Marx and the class struggle, but Adamic lays down the gauntlet; before that happens, Marxist intellectuals need to truly open their eyes to the brutal underbelly of American life.

Worker run book publisher and distributor AK Press is to be commended for re-publishing Dynamite, complete with a revealing "Forward" by Jon Bekken that locates Dynamite in the context of Louis Adamic's other works. AK Press has looked beyond its anarchist mandate to publish a work that at times seems to suggest that the function of labour violence has been to save capitalists from themselves. That said, Dynamite is a hard hitting, honest, and revealing exposé of the brutal and unrelenting violence of American capitalism.

Desperation, Adamic quite rightly argues, breeds violence, and in terroristic acts we see "the horror of desperate men thrown out of work with their families on the verge of starvation" (249). Put Dynamite on your to-read list; it is a heartfelt appeal for understanding of American workers who have been driven, and will continue to be driven, to not-so-quiet acts of desperation.

Peter Campbell

Queen's University

\title{
Rebecca N. Hill, Men, Mobs, and Law: Anti-Lynching and Labor Defense in U.S. Radical History (Durham, N.C.: Duke University Press, 2008).
}

Some historians work within tightly bounded areas: one particular event, or institution, or place, at one particular time. Others, and Rebecca N. Hill falls in this category, look across a broader expanse of the past and see connections between different segments that are generally treated separately. Men, Mobs, and Law: Anti-Lynching and Labor Defense in U.S. Radical History traces the "history of both anti-lynching campaigns and radical defense from the era of abolitionism until the New Left" (3). From that brief description, it should be clear that Hill has set herself an ambitious task, and the book that results is challenging but very worthwhile.

What the campaigns discussed here (John Brown, Haymarket, antilynching, various IWW campaigns, Sacco and Vanzetti, Scottsboro, the Rosenbergs, and George Jackson) have in common is that the state and its judicial apparatus is figured as the enemy of justice, particularly for those working for social and political change. Even the anti-lynching campaigns of Ida B. Wells and others sought social and political change, though they wanted more vigorous action by the legal system, not less. During the period under discus- 
sion, the power of the state expanded tremendously, notably during the Civil War and World War I, and one theme running throughout Men, Mobs, and Law is how radical social movements were able to build and use alternative institutions to put pressure on the state in defense campaigns. This is seen perhaps most clearly in the case of Haymarket, where two key figures (Albert Parsons and August Spies) were newspaper editors. There were other institutions that worked to maintain the status quo. By deftly moving between different episodes stretched across a century and a half, Hill shows many manifestations of what she sometimes describes as the "police-mob continuum" (15). In fact, the power of this structure, which had at its disposal both the mechanisms of the state and law enforcement and, when convenient, the defiance of law, is in constant tension with the dream of many of these campaigns to see the defense of particular individuals lead to a broader social revolution.

In some ways, the phenomenon Hill is analyzing here is what appears to be the mere surface but is instead the deep structure. The rhetorical invocation of past heroes of the left can seem to be pro forma, not substantial, but Hill makes a convincing case that the connections she draws are not just things we can see in retrospect, but connections that were evident and fundamental to those making them at the time, an important part of radical movements' crafting of their own histories and identities. By looking carefully at publicity materials, newspaper and magazine articles, courtroom statements, and so on, Hill sketches out one of the important ways in which a movement made up of many small struggles by the weak against the strong sought to gain a strength of its own by finding parallels to present struggles in the past.

The writing in Men, Mobs, and Law is clear and engaging throughout, even passionate in the epilogue that brings the historical questions into a contemporary setting briefly. It is nonetheless sometimes a demanding book to read simply because of the amount of often complex material to be covered. In order to draw the connections between the forms used in these different events, Hill must at least lay out some basic facts and narrative about each. She does this as effectively as it is probably possible to do, but there are points where, for instance, the internecine struggles of the left in the 1920s that are the background to the Sacco and Vanzetti defense campaign become hard to follow.

With so much to like about Hill's book, it is unfortunate that Duke University Press did not give it a bit more care. Any book will have a few lapses of copyediting, but this one has too many and, more seriously, the footnote references do not match up with the footnotes for part of one chapter. And, as with too many books these days, there are notes but no bibliography. Those caveats aside, Hill has produced a useful study that should appeal to a wide range of scholars, not just radical and labour historians, but legal historians and sociologists interested in movement building. 